\title{
Readiness of Culinary Micro, Small and Medium Enterprises to Support the Development of West Java International Airport (WJIA) Kertajati (Case Study: Kertajati Village, Kertajati District, Majalengka Regency-Indonesia)
}

\author{
Ruri Rahmawati ${ }^{1 *}$, Asnita Frida Sebayang ${ }^{2}$, Aan Julia $^{3}$ \\ ${ }^{1,2,3)}$ Universitas Islam Bandung, J1 Tamansari No.1 Bandung \\ *Corresponding Author Email: rahmungguuri187@gmail.com
}

\section{Received: 13/09/2020}

Accepted: 27/09/2020

Keywords: Airport Development, s, Readiness Stage, SWOT Analysis

\begin{abstract}
The purpose of this research is to find out how the stages and strategies of handling the readiness of Micro, Small, and Medium Enterprises (MSME) entrepreneurs in supporting the development of West Java International Airport (WJIA) Kertajati. The method used is descriptive analysis method with a quantitative approach. Data collection was carried out through structured interviews and questionnaires with 4 respondents from culinary Micro, Small, and Medium Enterprises in Kertajati Village. Techniques for measuring community readiness using the Community Readiness Modelconsisting of no awareness, denial/resistance, vague awareness, preplanning, preparation, initiation, stabilization, expansion/confirmation, community ownership. The results showed that the readiness of Kertajati Village Culinary MSME actors in supporting the development of WJIA Kertajati using 5 readiness dimensions, namely having a score of 4.4 or being in the preplanning stage which means that the community already has an understanding of the issues/problems that must be solved together. The handling strategy uses quantitative SWOT with the result that the strength $(\mathrm{S})$ and opportunity $(\mathrm{O})$ factors have a higher score than the weakness $(\mathrm{W})$ and threat $(\mathrm{T})$ factors. So there are several strategies or policy implications that can be carried out, namely providing incentives or capital assistance to culinary actors in Kertajati Village.
\end{abstract}

\section{INTRODUCTION}

West Java International Airport (WJIA) Kertajati is an airport located in Kertajati District, Majalengka Regency, West Java. West Java International Airport Development (WJIA) is a development plan that has been regulated in West Java Provincial Regulation No. 13/2010. The Regional Regulation contains the Development and Development of West Java International Airport and Kertajati Aerocity. In the construction of an airport, revenue is only received from aviation activities, therefore to maintain competitiveness, a greater income is needed and is obtained from activities that are not directly related to aviation activities (non-aviation revenue) and this is a necessity in airport business (Kratzch and Sieg, 2011) in (Tjahjono \& Yuliawati, 2017). As a result, airports carry out a metamorphosis by cooperating with the surrounding environment to become an airport city (aerocity) and even expand it on a regional scale and become an aerotropolis (Kasada, 2010; Tjahjono \& Yuliawati, 2017). According to Jimika (2019), Aerocity's development plan is expected to increase the income and purchasing power of the local community, increase the level of welfare, create a local business climate, and generate jobs for the community. Therefore, the Kertajati Aerocity area is expected to be an engine of economic growth for the Majalengka Regency. Therefore it is hoped that with this area it will increase the development of local industries and open jobs that will reduce unemployment so that the level of community income increases and drives the economic growth rate of the Majalengka Regency. One of the local industries that can be developed is Micro, Small, and Medium Enterprises or what is often referred to as s, which is one of the sectors that can absorb a lot of labor (Gunartin, 2017). In line with the hope of the Kertajati Aerocity area which is expected to be an engine of growth for Majalengka Regency, the sector is considered appropriate to be one of the drivers of economic growth in Majalengka Regency and Kertajati District which is directly affected by the construction of Kertajati West Java International Airport (WJIA). The Ring 1 area of Kertajati District is the villages affected by the construction of the West Java Kertajati International Airport, including Kertajati, Bantarjati, Sukakerta, Kertasari, Sukamulya Villages. The number of culinary s in the Kertajati District, ring 1 area can be seen in Table 1. 
Table 1. Number of Culinary s in Kertajati District in 2018

\begin{tabular}{lccc}
\hline \multicolumn{1}{c}{ Village } & Food & Restaurant & Food stalls \\
\hline Kertajati & 12 & 4 & 67 \\
Bantarjati & 3 & 1 & 19 \\
Sukakerta & 3 & - & 17 \\
Kertasari & 6 & - & 13 \\
Sukamulya & 6 & - & 48 \\
\hline \multicolumn{1}{c}{ amount } & $\mathbf{3 0}$ & $\mathbf{5}$ & $\mathbf{1 6 4}$ \\
\hline
\end{tabular}

Source: Kertajati District, 2019.

Kertajati Village is the closest village to the airport and is the village that has the largest number of Micro, Small, Medium Culinary Enterprises compared to other villages affected by the construction of the Kertajati West Java International Airport (WJIA). The classic problem faced is low productivity. This situation is caused by internal problems faced by s, namely the low quality of human resources in management, organization, mastery of technology and marketing, weak entrepreneurship of actors, and limited access of s to capital, information, technology, and the role and other production factors (Tyas \& Safitri, 2014). The presence of the Kertajati West Java International Airport (WJIA) which changes the livelihoods of the people of Kertajati Village who are all in the agricultural sector must be able to adjust to new skills, namely in the management of s so that people are ready to face changes as a result of the impact of the Kertajati airport development. To advance s and increase their role in the local economy, of course, cannot be separated from the readiness of business actors as human resources who directly participate in the development of theses. Therefore, Kertajati village as the village closest to the airport also has the most $\mathrm{s}$ to face the changes faced, it requires the readiness of players to have competitiveness and adaptation in facing changes due to the presence of Kertajati airport.

\section{LITERATURE REVIEW}

Readiness according to Slameto (2010) in Iriani and Marlina (2014) is the overall condition of a person that makes him ready to respond or answer in a certain way to a situation, including physical, mental, and emotional conditions, needs for motives, and goals, as well as skills, knowledge. others that have been studied. Readiness is the extent to which a community is ready to take action on a problem. Readiness is a specific problem, can be measured, can be measured with various dimensions, can vary between dimensions, can vary across segments of the community, can increase success, and knowledge that is important for strategies and interventions(Plested, Jumper-thurman, \& Edwards, 2009). The concept of community readiness was developed by Tri-Ethnic for Prevention Research (2014) and makes a community readiness model which is divided into (9) nine stages (Hasibuan, 2019). In the(Law No. 20 of 2008, 2008)concerning Micro, Small and Medium Enterprises Chapter 1 General Provisions Article 1 What is meant by Micro Business is a productive business owned by an individual and/or an individual business entity that meets the criteria of a Micro Business is regulated in the Law. A small business is a productive economic business that stands alone, which is carried out by an individual or business entity that is not a subsidiary or branch of a company that is owned, controlled, or is a part, either directly or indirectly, of Medium and Large Enterprises that meet the criteria of the business. Small as referred to in this Law. Medium Enterprises are productive economic enterprises that are independent, carried out by individuals or business entities that are not subsidiaries or branches of companies that are owned, controlled, or become a part, either directly or indirectly, with a Small or Large Business with the number of net assets or annual sales proceeds as regulated in this Law. Large enterprises are productive economic enterprises carried out by business entities with a net worth or annual sales proceeds greater than Medium Enterprises, which include state-owned or private national businesses, joint ventures, and foreign businesses carrying out economic activities in Indonesia. According to (Nuhung, 2012) in Large enterprises are productive economic enterprises carried out by business entities with a net worth or annual sales proceeds greater than Medium Enterprises, which include state-owned or private national businesses, joint ventures, and foreign businesses that carry out economic activities in Indonesia. According to (Nuhung, 2012) in Large enterprises are productive economic enterprises carried out by business entities with a net worth or annual sales proceeds greater than Medium Enterprises, which include state-owned or private national businesses, joint ventures, and foreign businesses carrying out economic activities in Indonesia. According to (Nuhung, 2012) in(Setyanto, Samodra, \& Pratama, 2015)through entrepreneurship, s play a very important role in reducing unemployment, providing employment, reducing poverty, improving welfare, and building national character. The important role of the existence of $\mathrm{s}$ in Indonesia is increasingly felt in the process of national economic development in Indonesia. Initially, the existence of s was considered an important source of economic development in rural areas. However, during the current and future era of globalization, the role of $\mathrm{s}$ is increasingly important, namely as a source of foreign exchange for Indonesia's non-oil and gas exports (Tambunan, 2002; Prasetyo, 2008). The airport is an area on land and/or waters with certain boundaries that are used as a place for aircraft to land and take off, boarding and disembarking passengers, loading and unloading goods, and places of intra and intermodal transportation, equipped with safety and security facilities flights, as well as basic facilities and other supporting facilities (Setiani, 2015). One of the airport developments in the development of the Aerocity concept. The Aerocity concept in airport development might also 
develop a city-centered airport by combining airport-oriented business development, business people, and local people around the airport (Kasandra, 2013) in (Setiawan et al., 2018).

\section{METHODOLOGY}

This research study is the readiness of culinary micro, small, and medium enterprises in facing the development of Kertajati West Java International Airport. The method used in this research is a descriptive analysis method with a quantitative approach. The descriptive analysis method is a method in research by looking at the existing conditions or conditions so that they can be analyzed and conclusions can be made so that the existing problems can be understood. The definition of a descriptive-analytical method according to (Sugiono 2009: 29) (Hasibuan, 2019) is a method that serves to describe or provide an overview of the object under study through data or samples that have been collected as they are without analyzing and making general conclusions. In analyzing the data, the method used is The Community Readiness Model. This model was originally developed by the Tri-Ethnic Center at the College of Natural Sciences, 1995 Department of Psychology at Colorado State University (Hasibuan, 2019). The data used in this study are primary data and secondary data. Primary data sources are interviews conducted with four Kertajati culinary SMEs with various kinds of MSME products and have business permits from the village, requests for data from the manager of Kertajati West Java International Airport, namely Ms. Dian, the commercial section, explaining how s become WJIA trading partners., Then an interview was conducted with the Head of Kertajati Village Government Affairs, Mr. Wawan Wirawan, about the state of culinary s in Kertajati Village which has not yet developed much, superior products owned, Kertajati Village MSME cooperation with WJIA. This secondary data is data that is not from the source and describes the situation in general. The author's data is obtained from government agencies, namely the Kertajati Village Office, Kertajati Village Culinary MSME business actors, and the commercial division of Kertajati West Java International Airport. In obtaining secondary data, researchers obtained it through browsing the internet by looking for published literature studies such as literary journals,

The sampling method in this study uses key informants. The Community Readiness Model (CRM) from the Tri Ethnic for prevention center (2014) in (Hasibuan, et al. 2019) uses key respondents to answer questions conducted by researchers during the survey. Key informants are people who tend to know about the problem, not necessarily a leader or policymaker, depending on the problem, the key informants that will be used are different but they are all involved in the problem. Depending on the problem, about four or five respondents were deemed sufficient(Edwards, Jumper-thurman, Plested, Oetting, \& Swanson, 2000). In analyzing the data, the method used is The Community Readiness Model. This model was originally developed by the Tri-Ethnic Center at the College of Natural Sciences, 1995 Department of Psychology at Colorado State University (Hasibuan, 2019). There are five dimensions of society as follows: 1) community knowledge related to MSME; 2) Leadership; 3) community climate; 4) community knowledge efforts about MSME; 5) resources, namely the extent to which local resources (human resources, capital, superior products) to face WJIA development. After conducting the interview, the next stage is to determine the assessment of each key respondent interviewed by referring to the Tri-Ethnic for Prevention Research (2014) in (Hasibuan, 2019) with nine measurements of the stages of readiness, namely no awareness, denial/resistance, vague awareness, preplanning. , preparation, initiation, stabilization, expansion/confirmation, community ownership. After carrying out the final readiness stages in various dimensions of community readiness, the next step is to conduct a SWOT analysis (strengths, opportunities, weaknesses, threats). This SWOT analysis aims to find the right strategy in terms of internal and external conditions so that decisions can be taken effectively. This analysis is based on a logic that can maximize strength (strength).

\section{RESULT AND DISCUSSION}

In line with the identification of problems and research objectives, the discussion stated regarding readiness taken from the perspective of Micro, Small, and Medium Enterprises actors and strategies for handling SWOT Quantitative case studies in Kertajati Village, Kertajati District, Majalengka Regency. The process of knowing the readiness of business actors consists of five dimensions of readiness, namely general public knowledge regarding issues, leadership, community climate, efforts to knowledge about issues and resources. So to find out the readiness of business actors is assisted by using the Community Readiness Model method. The result of distributing questionnaires was the readiness of culinary players in Kertajati Village who had an average score of 4.4 or were in the preplanning stage. After distributing questionnaires and interviews, the following results were obtained.

\subsection{Business Actor Readiness Level}

From the results of data processing, the Kertajati Village business actor's readiness stage was obtained. The results of the calculation of the readiness stage per dimension are obtained from the average calculation of all scores with the number of dimensions. 
Table 2. Calculation of Business Actor Readiness Based on Key Respondents

\begin{tabular}{|c|c|c|c|c|}
\hline Dimensions & Score & $\begin{array}{l}\text { Readiness } \\
\text { Stage }\end{array}$ & $\begin{array}{c}\text { Ideal } \\
\text { Number }\end{array}$ & $\begin{array}{l}\text { The difference from } \\
\text { Ideal Number }\end{array}$ \\
\hline Public Knowledge About Issues & 4.8 & Preplanning & & 4.2 \\
\hline Leadership & 5.6 & Preparation & & 3.4 \\
\hline Community Climate & 3.7 & $\begin{array}{c}\text { Vague } \\
\text { Awareness }\end{array}$ & 9 & 5.3 \\
\hline Community Knowledge Efforts & 4.1 & Preplanning & & 4.9 \\
\hline Resource & 4.0 & Preplanning & & 5 \\
\hline Total & 22.2 & & & \\
\hline Average & 4.4 & Preplanning & & 4.6 \\
\hline
\end{tabular}

\subsubsection{Dimensions of Public Knowledge About Issues}

The score achieved by business actors in Kertajati Village in the dimensions of general knowledge efforts is 4.1 or is in the preplanning stage. WJIA trade, location for s and Kertajati Aerocity. Some business actors do not know about issues including how to become WJIA's trading partners, trading locations, and Kertajati Aerocity. This happens because business actors feel that there has been no socialization regarding this issue from the airport to players. Based on the results of interviews conducted by the authors, actors complained about the lack of socialization related to airport knowledge so that players had a lack of information related to airports.

\subsubsection{Leadership}

The leadership dimension is useful for knowing how far business owners and leaders are to get involved and be involved in problem-solving. The leadership dimension is at a score of 5.6 or is in the preparation stage. At this stage, there is an understanding that something has to be done and there may even be a group working on it. However, the effort was neither focused nor detailed. The leadership of business actors already exists but does not yet have concrete planning. The leadership carried out by the actors is an important factor in the management of $s$ in Kertajati Village. Several MSME entrepreneurs in Kertajati village have heard about some of the problems faced by MSME actors in airport development, but they don't know much. The owners of micro, small, and medium enterprises in Kertajati Village already know about the needs of consumers at the airport. Some MSME actors already know that this must be handled, that is, it is enough for business actors to work together with the team, be able to solve problems faced, and try to adapt to the changes that occur. But some MSME business actors also have limited knowledge regarding the problems they are facing, for example, they have not been able to increase innovation for their products. Resources owned by MSME actors are also limited and of low quality due to lack of education and training. Based on the results of interviews conducted by the author.

\subsubsection{Community Climate}

This community climate dimension has 3.7 or is at the Vague Awareness stage. At this stage, some people are aware of developing issues and the need to do something to overcome developing issues and the need to do something to overcome these issues. Several business actors already know and hear about various issues such as how to become a trading partner at Kertajati West Java International Airport. MSME players in Kertajati Village feel the positive impact of the construction of Kertajati West Java International Airport. The positive impact that was felt was that when the airport was built, it could open businesses such as boarding houses, rice stalls, and Kertajati specialties that were sold. But after the airport construction was completed, the positive things began to decrease. Business actors know that this is a problem that must be addressed but does not have strong motivation. Besides, business actors only have little or no knowledge because there is no direction from the local government.

\subsubsection{Community Knowledge Efforts}

The general knowledge dimension has a score of 4.8 or is in the preplanning stage. At this stage, some business actors already know the various problems/issues that have occurred and must be resolved together. General knowledge of MSME actors about the development of the Kertajati WJIA is general knowledge about problems/issues that are known to business actors. Several MSME business actors have heard about various issues such as how to become an airport trading partner, trading locations, and the number of fees.

\subsubsection{Resource}

This dimension has a score of 4.0 or is in the preplanning stage. At this stage, several MSME actors already have an understanding of the problem that must be solved together. MSME actors already have a sense of leadership but there is no concrete planning yet. The resources that manage many of the $\mathrm{s}$ are the result of the community's initiatives to open their businesses. However, the average education of MSME actors in Kertajati village is quite low. Many efforts have been 
carried out from generation to generation such as the rangginang (rice crackers) business. Meanwhile, there are opaque businesses that only produce when they receive requests from customers.

\subsection{SWOT analysis}

In the IFAS (Internal Strategic Factors Summary) analysis, the weight calculation results (B) X Rating (R) are obtained and there are the following results:

Table 3. Internal Factors (Strength and Weakness)

\begin{tabular}{|c|c|c|c|c|}
\hline No. & Internal factors & Weight (B) & Rating (R) & $\begin{array}{l}\text { Score } \\
(\mathbf{B} \times \mathbf{R})\end{array}$ \\
\hline \multicolumn{5}{|c|}{ A. Strength } \\
\hline 1. & WJIA Kertajati's plan to become an e-commerce cargo airport. & 0.12 & 3.75 & 0.45 \\
\hline 2. & $\begin{array}{l}\text { The great desire of business actors to become trading partners of } \\
\text { WJIA Kertajati. }\end{array}$ & 0.12 & 3.5 & 0.42 \\
\hline 3. & $\begin{array}{l}\text { Some human resources in Kertajati Village who have entrepreneurial } \\
\text { leadership such as able to work with a team, visionary, innovation, } \\
\text { able to solve problems, persistent, taking risks, able to adapt to } \\
\text { changes, knowing consumer needs, assertive. }\end{array}$ & 0.10 & 3 & 0.3 \\
\hline 4. & $\begin{array}{l}\text { Plans for the construction of an Integrated Service Center for } \\
\text { Cooperative Micro, Small, and Medium Enterprises (PLUT } \\
\text { KMSME) } 2020 \text {. }\end{array}$ & 0.12 & 3.75 & 0.45 \\
\hline 5. & The existence of a Champion MSME candidate program. & 0.11 & 3.5 & 0.38 \\
\hline 6. & PT Angkasa Pura opened a business gallery for s & 0.11 & 3.75 & 0.41 \\
\hline Tota & Value & 0.68 & & 2.41 \\
\hline \multicolumn{5}{|c|}{ B. Weaknesses } \\
\hline 1. & Lack of knowledge of business actors regarding Aerocity. & 0.09 & 1.5 & 0.13 \\
\hline 2. & The technology used is still manual or uses human labor. & 0.07 & 2 & 0.14 \\
\hline 3. & Less innovative products and less attractive product packaging. & 0.07 & 2 & 0.14 \\
\hline 4. & The quality of human resources is still relatively low. & 0.09 & 1.75 & 0.15 \\
\hline Scor & & $\mathbf{0 . 3 2}$ & & 0.56 \\
\hline Tota & value & 1.00 & & 2.97 \\
\hline
\end{tabular}

Source: Researcher Process, 2020.

In the EFAS (External Strategic Factor Strategy) analysis, the weight calculation results (B) X Rating (R) are obtained and there are the following results:

Table 4. External Factors (Opportunity and Threats)

\begin{tabular}{|c|c|c|c|c|}
\hline No. & External Factors & Weight (B) & Rating (R) & $\begin{array}{l}\text { Score } \\
(\mathbf{B} \times \mathbf{R})\end{array}$ \\
\hline \multicolumn{5}{|c|}{ A. Opportunities } \\
\hline 1. & $\begin{array}{l}\text { Business opportunities with the presence of Kertajati West Java } \\
\text { International Airport. }\end{array}$ & 0.12 & 4 & 0.48 \\
\hline 2. & Development of information, science, and technology. & 0.12 & 3.5 & 0.42 \\
\hline 3. & The presence of Aerocity will create a local business climate. & 0.15 & 3.75 & 0.56 \\
\hline 4. & Kertajati Airport is an airport that serves Umrah. & 0.15 & 3.75 & 0.56 \\
\hline 5. & Increased consumption patterns or purchasing power. & 0.12 & 3.25 & 0.39 \\
\hline \multicolumn{2}{|r|}{ Total Value } & 0.66 & & 2.41 \\
\hline \multicolumn{5}{|c|}{ A. Threat } \\
\hline 1. & It is expensive to rent a kiosk at WJIA Kertajati. & 0.04 & 2 & \\
\hline 2. & Lack of public interest in coming to Kertajati airport. & 0.05 & 1.75 & 0.08 \\
\hline 3. & The negative impact of globalization on the economy. & 0.08 & 1 & 0.08 \\
\hline 4. & Airport operations are not optimal. & 0.08 & 1.5 & 0.12 \\
\hline 5. & Uncertain economic conditions due to the Covid-19 pandemic & 0.09 & 1.25 & 0.11 \\
\hline \multicolumn{2}{|r|}{ Total Value } & 0.34 & & 0.47 \\
\hline \multicolumn{2}{|c|}{ Total } & 1.00 & & 2.88 \\
\hline
\end{tabular}


Table 5. Results of SWOT Matrix Analysis of the Readiness of Micro, Small and Medium Culinary Business Actors in supporting the development of West Java International Airport (WJIA) Kertajati

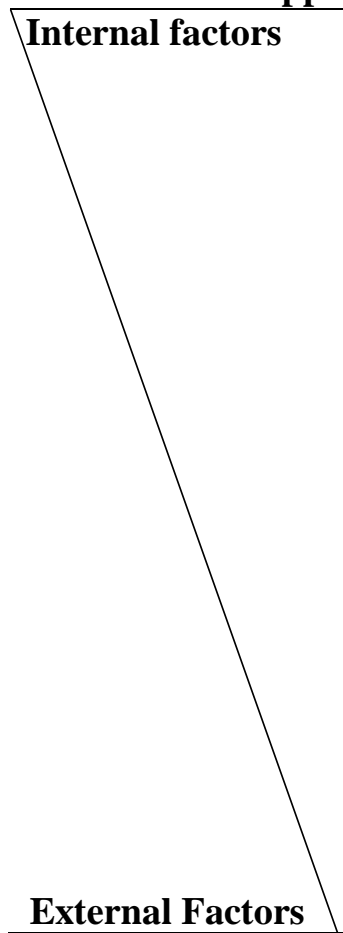

\section{Strength (S)}

1. WJIA Kertajati's plan to become an ecommerce cargo airport.

2. The great desire of business actors to become trading partners of WJIA Kertajati.

3. Several human resources in Kertajati Village who have such as being able to work with a team, are visionary, innovate, can solve problems, are persistent, take risks, can adapt to change, know consumer needs, firm.

4. Plans for the construction of an Integrated Service Center for Cooperative Micro, Small, and Medium Enterprises (PLUT KMSME) 2020.

5. The existence of a Champion MSME candidate program.

6. PT Angkasa Pura opened a business gallery for $\mathrm{s}$

\section{Weakness (W)}

1. Lack of knowledge of business actors regarding Aerocity.

2. The technology used is still manual or uses human labor.

3. Less innovative products and less attractive product packaging.

4. The quality of human resources is still relatively low.
Opportunity (O)

1. Business opportunities with the presence of Kertajati West Java International Airport.

2. Development of information, science, and technology.

3. The presence of Aerocity will create a local business climate.

4. Kertajati Airport is an airport that serves Umrah.

5. Increased consumption patterns or purchasing power.

\section{Threat (T)}

1. It is expensive to rent a kiosk at WJIA Kertajati.

2. Lack of public interest in coming to Kertajati airport.

3. The negative impact of globalization on the economy.

4. Airport operations are not optimal.

5. Uncertain economic conditions due to the Covid-19 pandemic

\section{SO strategy}

1. Provide incentives or capital assistance to culinary actors in Kertajati Village.

2. Increase programs or activities to support efforts to develop the local business climate.

3. Outreach to business actors regarding several plans and policies planned by the Government.
WO strategy

1. Conducted outreach from West Java International Airport (WJIA) regarding the plan to develop Kertjati Aerocity Airport.

2. Conducting business assistance or training.

\section{ST strategy}

1. Improving product quality by using halal labels and attractive packaging and competitiveness of $s$.

2. Improve the quality of Human Resources through

Science and Technology (IPTEK).

3. Making regulations or cooperation related to kiosk rental at Kertajati Airport with PT WJIA.

\section{WT strategy}

1. Improve the quality of infrastructure in the regions.

2. Doing product innovation.

3. Utilization of the development of Science and Technology (IPTEK). 


\subsection{Implications and Strategies}

Based on the results of the analysis with the previous SWOT matrix which resulted in the SO strategy as an optimal progressive strategy, it is necessary to have plans that are focused on the strategies resulting from the combination of strength and opportunity factors without forgetting the combination of other strategies. SO (Strength-Opportunity) strategies, among others, are as follows: 1) Providing incentives or capital assistance to culinary SMEs in Kertajati Village. Every effort to be able to run in operationalization and product productivity requires capital to be able to run the business. But the main weakness of $s$ at this time is the lack of business capital so that their businesses cannot develop optimally. Of course, incentive or capital assistance is needed so that the business is run can develop properly. The same is the case with the conditions of $\mathrm{s}$ in Kertajati Village which have difficulty in terms of capital ownership to develop their business so that the business they run cannot develop optimally. For this reason, strategies that can be used include a) Providing incentives or venture capital for actors in Kertajati Village; b) Credit interest subsidy for s; c) Providing incentives or assistance for security deposits to open outlets/tenants at Kertajati airport. 2) Increasing programs or activities to support efforts to develop the local business climate. The presence of Kertajati West Java International Airport (WJIA) is expected to accelerate the development and economic growth of the Majalengka Regency and its surrounding areas. Several strategies that can be implemented to support the development of a local business climate include: a) Strategies for improving the quality of human resources through training and business assistance; b) Strategies to increase product sales in the market by strengthening aspects of promotion that are more effective and advertisements that vary according to target markets; c) Utilizing and maintaining local wisdom from products to attract more buyers; d) Strengthening business institutions, financing systems and market opportunities for s. 3) Conducting outreach to business actors regarding several plans and policies planned by the Government. To increase the readiness and knowledge of Micro, Small, and Medium Enterprises actors, it is necessary to conduct socialization related to several plans and policies that exist or are being planned by the government. both the central, provincial, and local governments to increase the knowledge of business actors so that they can take advantage of existing opportunities. Some of the policies implemented by the central government include: 1) cutting interest rates on People's Business Credit (KUR), 2) reducing taxes, 3) and providing marketing and training assistance, 4) until the latest implementation of Online Single Submission (OSS).

\section{CONCLUSIONS}

According to the results of the research, the readiness stage of the Culinary Micro, Small and Medium Enterprises, Kertajati Village, Majalengka District, Majalengka Regency, which has the dimension with the highest score is the fourth dimension, namely the effort of community knowledge about issues. Meanwhile, the dimension with the lowest score was the community climate of 3.7 or was in the Vague Awareness stage. According to the results of the research, the readiness stage of culinary Micro, Small and Medium Enterprises, Kertajati Village, Majalengka District, Majalengka Regency is at a score of 4.4 or is in the preplanning stage. The preplanning stage means that business actors in Kertajati Village already have an understanding of the problems that must be solved, but these efforts have not been focused or detailed. Culinary players in Kertajati Village understand the problems they face, such as a lack of knowledge about issues such as Kertajati Aerocity, information regarding how to become WJIA Kertajati's trading partners, trading locations, and the number of costs. However, the business actors do not get direction from related parties so that the business actors lack information. According to the results of the study using a SWOT analysis of the readiness of Micro, Small, and Medium Culinary Business actors in Kertajati Village, Majalengka District, Majalengka Regency, the handling strategy used Quantitative SWOT with the results that the strength (S) and opportunity $(\mathrm{O})$ factors had a higher score than the weakness factor (W) and threats $(\mathrm{T})$. then several strategies can be done, namely attracting investors to invest in Kertajati Airport. Increasing programs or activities to support efforts to develop the local business climate. Outreach to business actors regarding several plans and policies planned by the Government.

\section{ACKNOWLEDGMENT}

The author would like to thank both parents, family, and friends who have given their encouragement and support. The author also wishes to express his deepest gratitude to all Development Economics lecturers who have provided knowledge and do not forget to thank the alma mater of the Islamic University of Bandung, which is the place for writers to seek knowledge. The author also thanks all respondents from this research for all their help, time, and willingness to help the author so that the author can complete this research.

\section{REFERENCES}

Edwards, R. W., Jumper-thurman, P., Plested, B. A., Oetting, E. R., \& Swanson, L. (2000). A RT I C L E COMMUNITY READINESS : RESEARCH TO PRACTICE. 28(97), 291-307.

Gunartin. (2017). 59 | G u n a r t i n. EDUKA Jurnal Pendidikan, Hukum Dan Bisnis, 1(V), 59-74.

Jimika, F. (2019). The Impact Of Kertajati Airport On Economic Structure Of Majalengka. Maro: Jurnal Ekonomi Syariah Dan Bisnis, 3(1), 11-21. Plested, B. A., Jumper-thurman, P., \& Edwards, R. W. (2009). Community Readiness Manual. Prevention, 65. 
Prasetyo, P. E. (2008). Peran Usaha Mikro Kecil dan Menengah (MSME) dalam Kebijakan Penanggulangan Kemiskinan dan Pengangguran. Jurnal Akuntansi Dan Manajemen , 2(1), 1-13.

Setiani, B. (2015). Prinsip-Prinsip Manajemen Pengelolaan Bandar Udara. Jurnal Ilmiah WIDYA, 3(1), 25-35.

Setiawan, M. I., Surjokusumo, S., Ma'Soem, D. M., Johan, J., Hasyim, C., Kurniasih, N., .. Wajdi, M. B. N. (2018). Business Centre Development Model of Airport Area in Supporting Airport Sustainability in Indonesia. Journal of Physics: Conference Series, 954(1). https://doi.org/10.1088/1742-6596/954/1/012024

Setyanto, A. R., Samodra, B. R., \& Pratama, Y. P. (2015). Kajian Strategi Pemberdayaan MSME Dalam Menghadapi Perdagangan Bebas Kawasan ASEAN (Studi Kasus Kampung Batik Laweyan). Etikonomi, 14(2), 205-220. https://doi.org/10.15408/etk.v14i2.2271

Tjahjono, T., \& Yuliawati, E. (2017). Bandar Udara Internasional Jawa Barat (BIJB) dan Potensi Kertajati Sebagai Aerocity. Warta Ardhia, 43(1), 43. https://doi.org/10.25104/wa.v43i1.274.43-50

Tyas, A., \& Safitri, V. (2014). Penguatan Sektor MSME sebagai Strategi Menghadapi Mea 2015. Jurnal Ekonomi Universitas Esa Unggul, 5(1), 17895.

UU No. 20 Tahun 2008. (2008). UU No. 20 Tahun 2008. UU No. 20 Tahun 2008, (1), 1-31. 